\title{
THE EFFECT OF FINANCIAL DEVELOPMENT ON ECONOMIC GROWTH COUNTRIES ASEAN-4
}

\author{
Rizka Lailatul Millah ${ }^{1}$ \\ Wisnu Wibowo*2
}

1,2 Faculty of Economics and Business, Universitas Airlangga, Indonesia

\section{ABSTRACT}

This study aims to determine the effect of financial development on economic growth in ASEAN-4 during 1999-2018. This study uses the regression method and panel approaches using the Fixed Effect Model method. This research uses the FEM quantitative method and uses a stata 13 estimation tool. The panel data regression results in this study indicated that financial development has a positive relationship with economic growth. This is evident from the three financial development proxies, which have a positive correlation with economic growth domestic credit to private sector, money broad variables, market capitalization and degree of openness to reflect the real sector.

Keywords: financial development, degree of openness, economic growth JEL : G2, 011, 016

\section{ABSTRAK}

Penelitian ini bertujuan untuk mengetahui pengaruh pengembangan keuangan terhadap pertumbuhan ekonomi negara ASEAN-4 pada tahun 1999 - 2018. Studi ini menggunakan pendekatan metode regresi dan panel menggunakan metode Fixed Effect Model. Penulis menggunakan metode kuantitatif FEM dan menggunakan alat estimasi stata 13. Hasil regresi data panel dalam penelitian ini menunjukkan bahwa financial development memiliki hubungan yang positif terhadap pertumbuhan ekonomi. $\mathrm{Hal}$ ini terlihat dari tiga proxy pengembangan keuangan yaitu likuiditas yang dicerminkan oleh jumlah uang beredar dan kredit yang disalurkan berdampak positif signifikan, kapitalisasi pasar dan didukung oleh keterbukaan perdagangan untuk mencerminkan sektor riil.

Kata Kunci : Pengembangan keuangan, keterbukaan perdagangan, pertumbuhan ekonomi

JEL : G2, 011, 016

\section{RIWAYAT ARTIKEL}

Tanggal Masuk: 25 Agustus 2021 Tanggal Revisi: 24 September 2021 Tanggal Diterima: 24 Oktober 2021 Tersedia online: 29 November 2021

${ }^{*}$ Correspondence:

Wisnu WIbowo E-mail: wisnuwibowo@feb.unair. ac.id 


\section{Pendahuluan}

Pengembangan pada sektor keuangan akan memberikan informasi terkait kemungkinan investasi yang lebih menguntungkan dan mendorong untuk mengalokasikan modal secara maksimal. Menurut Beck \& Demirguc-Kunt (2006) sistem keuangan yang berfungsi dengan baik dianggap menjadi salah satu fondasi utama dalam membangun ekonomi yang berkelanjutan. Namun tidak ada konsensus tentang hubungan antara pengembangan keuangan dan pertumbuhan ekonomi yang menjadi salah satu masalah yang diperdebatkan. Awalnya ada dua aliran pemikiran utama. Para pendukung aliran pemikiran pertama atau klasik berpendapat bahwa pengembangan keuangan sangat diperlukan untuk pertumbuhan ekonomi (Levine, 1997). Namun faktanya, keuangan mempengaruhi pertumbuhan dengan mempengaruhi tabungan, inovasi teknologi dan investasi (Demirguc-Kunt, 2006). Namun para pendukung aliran kedua, atau neoklasik berpendapat bahwa keuangan bukanlah sumber utama pertumbuhan (Lucas, 1988).

Menurut King \& Levine (1993) perkembangan keuangan akan menstimulasi pertumbuhan ekonomi dengan adanya akumulasi modal. King \& Levine (1993) menyatakan bahwa ada 4 cara pengembangan sektor keuangan yang mendorong kepada pertumbuhan yaitu: perbaikan pada sistem keuangan akan mendorong produktivitas melalui wirausaha karena berpotensi untuk mendapatkan profit yang besar, menyediakan mobilisasi pembiayaan eksternal untuk para pengusaha, menyediakan kendaraan yang unggul untuk diversifikasi risiko dan menganalisis potensi keuntungan bisnis.

Beck et al. (2000) menyimpulkan bahwa lembaga mediasi keuangan memberikan dampak yang besar pada total pertumbuhan produktivitas yang akan mempengaruhi pertumbuhan PDB total. Model pertumbuhan endogen juga berpendapat bahwa lembaga keuangan mempengaruhi pertumbuhan dengan mengubah tabungan (Levine, 1997). Namun, Jayaratne \& Strahan (1996) tidak menemukan bukti untuk mendukung pandangan bahwa pasar keuangan meningkatkan pertumbuhan ekonomi dengan meningkatkan investasi dan tabungan secara keseluruhan.

Menurut Beck dkk (2000) bahwa financial development mampu memberikan pengaruh terhadap pertumbuhan ekonomi melalui peningkatan teknologi dengan alokasi tabungan yang lebih baik atau dengan akumulasi modal dengan meningkatkan jumlah tabungan domestik dan modal asing. Perkembangan sektor keuangan dapat ditunjukkan dengan jumlah uang beredar di masyarakat untuk mengetahui likuiditas perekonomian, lebih mikro lagi dapat diukur dengan kredit yang disalurkan oleh lembaga keuangan.

Kredit yang disalurkan dalam dua dekade terakhir, akses kredit di Asia Tenggara terus mengalami kenaikan, setelah sempat jatuh pada periode 2008-2009. Kemudahan aksesibilitas pada sektor keuangan akan menciptakan stabilitas keuangan, pertumbuhan, pengurangan kemiskinan, dan pendistribusian sumber daya serta kapasitas yang lebih seimbang (DemirgüçKunt et al., 2008; Purwono et al., 2021).

Botev et al. (2019) menjelaskan bahwa efek positif dari kredit yang disalurkan oleh sektor keuangan memiliki efek lebih besar daripada pergerakan harga saham, karena pergerakan sektor riil lebih jelas dirasakan dampaknya ketika uang yang disalurkan langsung dimanfaatkan untuk produksi.

Kindleberger (1963) mengemukakan pandangan bahwa kontribusi pembangunan keuangan pada pertumbuhan ekonomi tergantung pada kondisi suatu ekonomi negara. Dia 
berpendapat bahwa negara yang terbelakang secara ekonomi atau bisa dikatakan dengan negara berpendapatan menengah dan pendapatan rendah membutuhkan pengembangan sistem keuangan yang lebih dibandingkan negara-negara maju.

Penelitian Ibrahim \& Alagidede (2018) pada menjelaskan hasil financial development memiliki pengaruh positif terhadap pertumbuhan ekonomi, namun dalam penelitiannya menyebutkan bahwa financial development akan menjadi bencana ketika perbaikan sektor keuangan tidak sesuai dengan sektor riil.

Penelitian Seven \& Yetkiner (2016) dalam penelitiannya terkait hubungan lembaga perbankan, pasar saham dan pertumbuhan ekonomi menjelaskan bahwa pada negara berpendapatan rendah dan menengah memiliki hubungan yang positif, tetapi pada negara maju sebaliknya, yaitu berhubungan negatif.

Perbedaan hasil dari penelitian sebelumnya juga menemukan hasil bahwa financial development masih diperdebatkan karena memiliki pengaruh negatif dan pengaruh positif terhadap pertumbuhan ekonomi, pernyataan dari Gerschenkron juga menyatakan bahwa financial development akan memiliki dampak yang berbeda pada negara berpendapatan tinggi dan berpendapatan rendah. Hal ini menjadi pendorong penulis untuk melakukan penelitian secara empiris menggunakan objek penelitian dari negara berpendapatan menengah kebawah, khususnya negara Indonesia, Malaysia, Filiphina dan Thailand untuk mengetahui pengaruh financial development terhadap pertumbuhan ekonomi.

Berdasarkan latar belakang yang telah dijabarkan, maka dapat disimpulkan penelitian ini bertujuan untuk menganalisis pengaruh financial development yang didasarkan oleh likuiditas yang dicerminkan oleh broad money, kemudahan akses permodalan dijabarkan oleh credit provided by financial sector, kapitalisasi pasar yang mencerminkan ekonomi riil oleh perusahaan yang merupakan kategori industri dan degree of openness terhadap pertumbuhan ekonomi negara ASEAN-4 (Indonesia, Malaysia, Filiphina, Thailand) pada periode 1999-2018

\section{Telaah Literatur}

Teori Harrod-Domar menjelaskan dalam mencapai pertumbuhan ekonomi yang teguh atau steady growth pada jangka panjang ada syarat-syarat yang harus dipenuhi. Harrod-Domar dalam analisisnya menggunakan perumpamaan sebagai berikut (i) barang modal kapasitasnya telah penuh, (ii) tabungan adalah proporsional dengan pendapatan nasional (iii) rasio modal-produksi tidak berubah nilainya dan (iv) perekonomian berasal dari dua sektor. Pertumbuhan ekonomi akan meningkat sejalan dengan meningkatnya investasi jangka panjang. Investasi dapat meningkatkan pertumbuhan ekonomi karena memiliki peran ganda yaitu menciptakan efek permintaan yang berguna meningkatkan pendapatan dan efek penawaran yang mampu meningkatkan kapasitas produksi.

Teori pertumbuhan neo-klasik dikembangkan oleh Solow dan Swan pada tahun 1956 yang terkenal dengan "the law of diminishing returns". Model Solow-Swan menggunakan unsur pertumbuhan penduduk, akumulasi modal, kemajuan teknologi dan besarnya output yang saling berinteraksi.

Mankiw (2006) menjelaskan bahwa penawaran barang dalam model Solow didasari oleh fungsi produksi yang sudah dikenal, yang menyatakan bahwa output yang dihasilkan bergantung pada persediaan modal dan angkatan kerja. Persamaan model pada fungsi produksi adalah: 


$$
Y=A F(K, L)
$$

Dimana, $Y=$ output, $A=$ kemajuan teknologi sebagai variabel eksogen, $K=$ modal, dan $L=$ tenaga kerja.

Penelitian oleh Pradhan et al. (2016) yang menggunakan metode Vector Error Corection Model (VECM) menunjukkan keterkaitan perkembangan sektor keuangan dan meningkatnya inovasi, pada berpengaruh terhadap pertumbuhan ekonomi pada jangka panjang.

Penelitian Ono (2017) dengan judul "Financial Development and Economic Growth Nexus in Rusia" menggunakan metode Vector Autoregression Model, dengan periode yang diteliti tahun 1999 - 2008 dan periode kedua yaitu 2009 - 2014. Pada periode pertama menjelaskan bahwa ada hubungan timbal balik antara pertumbuhan ekonomi dan kredit yang disalurkan bank, sedangkan pada periode kedua tidak terjadi hubungan timbal balik antara kredit yang disalurkan oleh bank dari penawaran uang terhadap pertumbuhan ekonomi.

Ansong et al. (2012) dalam penelitiannya menganalisis dampak dari inovasi keuangan pada tingkat tabungan di Ghana periode tahun 1963 sampai 2006. Melalui metode VECM memperlihatkan hasil bahwa jumlah uang beredar (MI/M2) berhubungan positif dalam jangka panjang, namun berhubungan negatif pada jangka pendek. Variabel makroekonomi, seperti GDP, inflasi, suku bunga deposit dan pinjaman, serta nilai tukar memiliki hubungan signifikan terhadap tabungan.

Asteriou \& Spanos (2019) dalam penelitiannya yang berjudul "the Relationship between Financial Development and Economic Growth during the Recent Crisis: evidence from the EU" menganalisis hubungan financial development pada periode 1990-2016 dengan sample 26 negara bagian di Eropa yang menunjukkan pertumbuhan ekonomi sebelum dan sesudah krisis, hasilnya pada sebelum krisis financial development memicu pertumbuhan ekonomi dan setelah krisis terjadi sebaliknya, dan memproteksi deposit mendorong stabilitas sistem keuangan. Temuan pada 2008 dan 2009 menunjukkan bahwa rasio aset pada bank komersial menjaga perekonomian agar tidak jatuh dan kecukupan modal bank mendorong stabilitas sistem keuangan.

Odhiambo (2008) dalam penelitiannya yang berjudul "Financial Depth, Savings and Economic Growth in Kenya: A Dynamic Causal Linkage" penelitian ini menggunakan sample dari 1991-2005 dan menjelaskan pada hasil empiris bahwa terjadinya pertumbuhan ekonomi akan meningkatkan tabungan sementara dan menyebabkan financial development meningkat di Kenya, hal ini berlaku pada formulasi statis maupun dinamis, oleh karena itu financial development harus dilakukan secara hati-hati.

Durusu-Ciftci et al. (2017) dalam penelitiannya yang berjudul "Financial Development and Economic Growth: Some Theory and More Evidence" dengan periode penelitian mulai tahun 1989-2011 menemukan hasil bahwa penyaluran kredit dan perkembangan pasar saham pada jangka panjang berdampak positif terhadap pertumbuhan PDB perkapita, namun efektifitas pengaruhnya masih lebih kuat terletak pada pengembangan sektor perbankan karena pasar saham masih dinilai belum berkontribusi secara maksimal pada negara berpenghasilan rendah, sedangkan bank memiliki efek positif yang cukup besar pada alokasi modal.

Vergara (2018) pada penelitiannya yang berjudul "Financial Development, Institutional Investors, and Economic Growth" yang menggunakan sample 116 negara pada periode 19912014 yang membahas hubungan nonlinear antara perkembangan keuangan dan pertumbuhan ekonomi. Hasilnya kredit bank pada sektor swasta memiliki dampak positif dan lebih be- 
sar pengaruhnya dibandingkan dengan kontribusi nilai tambah industri. Institusi investor juga berdampak positif terhadap pertumbuhan ekonomi, khususnya pada PDB perkapita.

Ductor \& Grechyna (2015) dalam penelitiannya yang berjudul "Financial Development, Real Sector and Economic Growth" menggunaka 101 sample negara pada periode 1970- 2010 menunjukkan bahwa ada hubungan saling ketergantungan antara sektor keuangan dan sektor riil yang berpengaruh pada pertumbuhan PDB. Akselerasi pengembangan sektor keuangan yang tidak disertai dengan pertumbuhan sektor riil akan mengurangi efek positif dari pengembangan sektor keuangan, efek ini bahkan bisa menjadi efek negatif jika perkembangan sektor keuangan tumbuh secara substansial lebih cepat dibandingkan dengan output riil. Berdasarkan rumusan masalah, tinjauan teoritis, dan tinjauan empiris dalam penelitian ini, maka dapat disusun hipotesis penelitian sebagai berikut :

1. Indikator financial development berupa broad money berpengaruh signifikan positif terhadap pertumbuhan ekonomi negara ASEAN-4.

$\mathrm{HO}=0$ broad money tidak mempengaruhi pertumbuhan ekonomi negara ASEAN-4

$\mathrm{H} 1 \neq 0$ broad money mempengaruhi pertumbuhan ekonomi negara ASEAN-4

2. Indikator financial development berupa kredit yang disalurkan oleh sektor keuangan berpengaruh signifikan positif terhadap pertumbuhan ekonomi negara ASEAN-4.

$\mathrm{HO}=0$ Domestic credit provided by financial sector tidak mempengaruhi pertumbuhan ekonomi negara ASEAN-4

$\mathrm{H} 1 \neq 0$ Domestic credit provided by financial sector mempengaruhi pertumbuhan ekonomi negara ASEAN-4

3. Indikator financial development berupa market capitalization berpengaruh signifikan positif terhadap pertumbuhan ekonomi negara ASEAN-4.

$\mathrm{HO}=0$ market capitalization tidak mempengaruhi pertumbuhan ekonomi negara ASEAN-4 $\mathrm{H} 1 \neq 0$ market capitalization mempengaruhi pertumbuhan ekonomi negara ASEAN-4

4. Indikator degree of opennes berpengaruh signifikan positif terhadap pertumbuhan ekonomi negara ASEAN-4.

$\mathrm{HO}=0$ degree of opennes tidak mempengaruhi pertumbuhan ekonomi negara ASEAN-4 $\mathrm{H} 1 \neq 0$ degree of opennes mempengaruhi pertumbuhan ekonomi negara ASEAN-4.

\section{Metode Penelitian}

Metode ini menggunakan metode analisis kuantitatif dengan menggunakan data panel. Penelitian ini berfokus untuk mengetahui signifikansi hubungan antara variable financial development yang dicerminkan oleh jumlah uang yang beredar, jumlah kredit yang disalurkan lembaga keuangan, kapitalisasi pasar dan keterbukaan perdagangan terhadap pertumbuhan ekonomi pada empat negara berkembang ASEAN-4 pada periode 1999 - 2018.

Model empiris yang digunakan untuk menjelaskan hubungan antara variabel dependen dan independen dalam penelitian ini adalah data panel. Berikut adalah model analisis yang digunakan:

$$
G d p g=\beta_{0 i t}+\beta_{1} b m_{i t}+\beta_{2} d c f s_{i t}+\beta_{3} \ln \text { mcapt }_{i t}+\beta_{5} \text { trade }_{i t}+\varepsilon_{i t}
$$




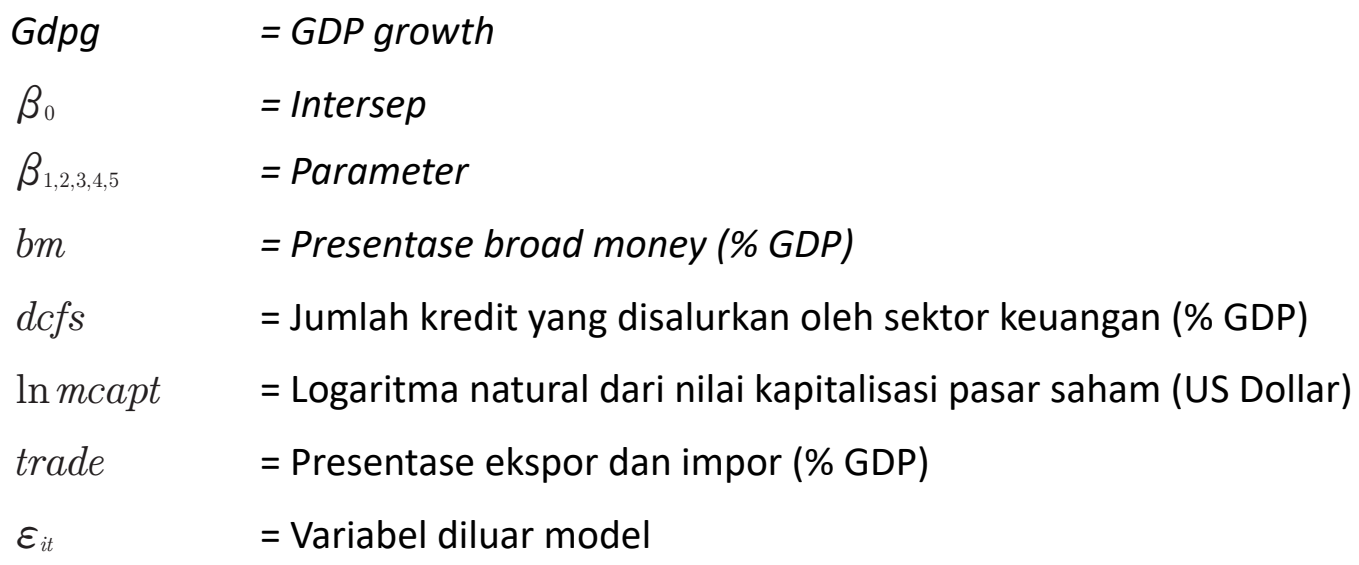

Tabel 1: Jenis dan Sumber Data

\begin{tabular}{cccc}
\hline \hline No & Variabel & Jenis Data & Sumber Data \\
\hline \hline 1 & GDP growth & Sekunder & World Bank \\
\hline \hline 3 & Broad money & Sekunder & World Bank \\
\hline \hline 4 & $\begin{array}{c}\text { Domestic credit } \\
\text { provided by financial } \\
\text { sector }\end{array}$ & Sekunder & World Bank \\
\hline \hline 5 & Market Capitaliza- & Sekunder & World Bank \\
\hline \hline
\end{tabular}

Sumber: World Bank (2019)

Beberapa pengujian tersebut antara lain Uji Chow atau uji F restricted merupakan pengujian statistik untuk dasar pemilihan menggunakan model pooled least square atau model fixed effect, uji Hausman bertujuan untuk mencari model terbaik diantara FEM dan REM dan uji LM adalah ujian statistik untuk pemilihan gunakan model fixed effect model atau random effect model. Uji asumsi klasik bertujuan untuk menguji kelayakan model regresi yang digunakan dalam penelitian. Model penelitian dikatakan model yang layak apabila memenuhi asumsi BLUE (Best Linear Unbiased Estimator), yakni melalui uji multikolinearitas dengan melihat nilai VIF atau nilai 1/VIF pada masing-masing variabel independen, uji heterokastisitas, autokorelasi, t-parsial test, uji F simultan dan R-squared.

\section{Hasil dan Pembahasan}

\section{Analisis Deskriptif Data}

Hasil statistik deskriptif dengan pada tujuh variabel yang berkaitan dengan penelitian dijelaskan sebagai berikut : Total observasi adalah 80 dengan rincian time series sebanyak 20 tahun dan cross section sebanyak 4 negara. Pada tabel 2 merupakan statistik deskriptif dari data variabel-variabel yang digunakan dari tahun 1999-2018. GDP growth memiliki nilai rata-rata 4,88, standar deviasi 1,92 nilai terkecil -1,51 dan pertumbuhan maksimum 8,86. Untuk jumlah uang beredar dari 80 sampel yang digunakan ditemukan nilai rata-rata jumlah uang beredar sebesar $88,1 \%$ dari GDP, standart deviasi 37 , jumlah uang beredar terkecil $36 \%$ dan jumlah uang terbesar $140 \%$ dari GDP.

Kredit yang disalurkan oleh sektor keuangan rata-rata 87,6\%, standart deviasi 39,9\%, dengan minimum $33,3 \%$ and kredit terbesar yang disalurkan mencapai $158 \%$ dari GDP. Rasio 
Keterbukaan perdagangan terhadap GDP dengan rata-rata 108,4\%, standart deviasi 49,6\%, nilai minimum 37,4\% dan rasio keterbukaan terbesar sebesar $220 \%$ dari GDP. Rasio kapitalisasi pasar, dengan nilai rata-rata 35,8\% dari GDP, standart deviasi 0,96\% nilai terkecil $23,6 \%$ dan nilai terbesar $27 \%$.

Tabel 2: Statistik Deskriptif Data

\begin{tabular}{cccccc}
\hline Variabel & $\begin{array}{c}\text { Jumlah Obser- } \\
\text { vasi }\end{array}$ & Mean & Standar deviasi & Minimum & Maximum \\
\hline Gdpg & 80 & 4,88 & 1,92 & $-1,51$ & 8,86 \\
\hline BM & 80 & 88,1 & 37 & 36 & 140 \\
\hline Dcfs & 80 & 87,6 & 39,9 & 33,3 & 150,8 \\
\hline Lnmcapt & 80 & 25,8 & 0,96 & 23,6 & 27,0 \\
\hline Trade & 80 & 108,4 & 49,6 & 37,4 & 220 \\
\hline
\end{tabular}

Sumber : Hasil Penghitungan Penulis

\section{Hasil Estimasi}

Pada data panel terdapat tiga metode estimasi, yaitu PLS (Pooled Least Square), FEM (Fixed Effect Method) serta REM (Random Effect Method). Setelah melalui pengujian dengan metode estimasi, yang dipilih adalah model Fixed Effect Model (FEM). Secara ringkas tabel 4.2 menjelaskan hasil regresi. Variabel independen terdiri dari jumlah uang beredar berpengaruh positif signifikan terhadap pertumbuhan ekonomi, variabel dependen kredit domestik dari lembaga keaungan yang disalurkan berpengaruh positif signifikan terhadap pertumbuhan ekonomi, kapitalisasi pasar variabel berpengaruh positif signifikan terhadap pertumbuhan ekonomim, keterbukaan perdagangan berpengaruh positif signifikan terhadap pertumbuhan ekonomi

Tabel 3: Hasil Estimasi Model Pengaruh Financial Development terhadap Pertumbuhan Ekonomi Negara ASEAN-4 Periode 1999-2018

\begin{tabular}{cccc}
\hline Variabel & \multicolumn{3}{c}{ Variabel dependen: Logaritma GDP } \\
\hline Independen & PLS & FEM & REM \\
\hline Bm & 0.001045 & 0.0000353 & 0.001045 \\
\hline Dcfs & $(0.0003385)^{*}$ & $(0.0001999)^{* * *}$ & $(0.0003385)^{*}$ \\
\hline & 0.0015314 & 0.000041 & 0.0015314 \\
\hline Lnmcap & $(0.0002668)^{*}$ & $(0.0001482)^{* * *}$ & $(0.0002668)^{*}$ \\
\hline & 0.0420946 & 0.241807 & 0.420946 \\
\hline Openness & $(0.0030062)^{*}$ & $(0.001623)^{*}$ & $(0.0030062)^{*}$ \\
\hline & 0.0005409 & -0.0001836 & 0.0005409 \\
\hline R-square & $(0.0001115)^{*}$ & $(0.0000683)^{*}$ & $(0.0001115)^{*}$ \\
\hline Observasi $(\mathrm{n})$ & 0.9071 & 0.8680 & 0.6802 \\
\hline
\end{tabular}

Sumber: hasil penghitungan penulis

Hubungan antar variabel dependen dengan variabel independen berdasarkan hasil regresi diatas yaitu:

Hubungan jumlah uang uang beredar dengan GDP growth 
Koefisien regresi regresi sebesar 0,001045. P-value model sebesar 0.001 dimana nilai lebih kecil dari nilai $\alpha 5 \%$ maka berpengaruh signifikan. Sehingga dapat disimpulkan bahwa peningkatan jumlah uang beredar 1 persen akan meningkatkan pertumbuhan ekonomi sebesar 0,001045 persen.

\section{Hubungan Jumlah kredit yang disalurkan dengan GDP growth}

Hubungan Jumlah kredit yang disalurkan memiliki koefisien regresi sebesar 0,0015314. P-Value 0,000 dimana nilai lebih kecil dari nilai $\alpha$ 5\% maka signifikan terhadap GDP growth sehingga dapat disimpulkan bahwa peningkatan jumlah kredit yang disalurkan sebesar 1 persen akan meningkatkan GDP perkapita riil sebesar 0,0015314 persen.

\section{Hubungan kapitalisasi pasar dengan GDP growth}

Koefisien regresi trade opennes sebesar 0,420946 P-value model sebesar 0.000 dimana nilai lebih kecil dari nilai $\alpha 5 \%$ maka berpengaruh signifikan. Sehingga dapat disimpulkan bahwa peningkatan trade openness sebesar 1 persen akan menurunkan output sebesar 0,420946 persen.

\section{Hubungan keterbukaan perdagangan dengan GDP growth}

Koefisien regresi degree of opennes sebesar 0,0005409. P-value model sebesar 0.000 dimana nilai lebih kecil dari nilai $\alpha$ 5\% maka berpengaruh signifikan. Sehingga dapat disimpulkan bahwa peningkatan degree of opennes sebesar 1 persen akan menurunkan output sebesar 0,0005409 persen.

Tabel 4 di bawah ini menggambarkan arah hubungan model regresi fixed effect pada variabel pertumbuhan ekonomi yang diproksikan melalui gdpg. Hasil uji regresi menerangkan bahwa variabel jumlah uang beredar, kredit yang disalurkan oleh sektor keuangan, kapitalisasi pasar dan keterbukaan perdagangan mempunyai hubungan positif pada pertumbuhan ekonomi di ASEAN-4.

Tabel 4: Tanda Hasil Regresi Model

\begin{tabular}{clc}
\hline No. & \multicolumn{1}{c}{ Variabel Independen } & Tanda Hasil Regresi \\
\hline 1 & Jumlah uang beredar (BM) & + \\
\hline 2 & Kredit yang disalurkan oleh sektor keuangan (Dcfs) & + \\
\hline 3 & Logaritma kapitalisasi pasar (Inmcapt) & + \\
\hline 4 & Keterbukaan perdagangan (trade) & + \\
\hline
\end{tabular}

Sumber: Hasil penghitungan penulis

\section{Pembuktian Hipotesis}

Berdasarkan rumusan masalah, model analisis dan hasil pengujian hipotesis dalam penelitian menunjukkan financial development berpengaruh positif dan signifikan terhadap pertumbuhan ekonomi negara berkembang ASEAN-4. Hal tersebut dapat dilihat dari ketiga variabel yang menjadi proksi financial development, yaitu jumlah uang beredar, jumlah kredit yang disalurkan dan kapitalisasi pasar memiliki hubunga positif signifikan dengan pertumbuhan ekonomi. 


\section{Hubungan Jumlah Uang Beredar dan Pertumbuhan Ekonomi}

Hasil estimasi menunjukkan bahwa jumlah uang beredar berpengaruh positif dan signifikan terhadap pertumbuhan ekonomi. Nilai positif pada koefisien broad money adalah 0.001045 menjelaskan bahwa apabila terdapat peningkatan sebesar 0.001045 pada jumlah uang beredar maka akan meningkatkan GDP sebesar $0.001045 \%$ diempat negara ASEAN pada tahun 1999-2018 dengan asumsi variabel lain dianggap konstan. Hal ini berarti perkembangan jumlah uang beredar yang cenderung meningkat memberikan dampak yang signifikan terhadap pertumbuhan eknomi. Jumlah uang yang beredar di masyarakat akan menstimulus pertumbuhan ekonomi untuk menggerakkan sektor swasta dan meningkatkan produktifitas.

Beberapa penelitian juga sepakat mengenai dampak jumlah uang beredar akan meningkatkan pertumbuhan ekonomi. J. Lee (2005) melakukan penelitian serupa di Kanada , dan hasilnya jumlah uang beredar berpengaruh positif pada pertumbuhan ekonomi. Hasil penelitian ini juga sejalan dengan penelitian yang dilakukan oleh Levine \& Zervos (1998) yang menunjukkan hubungan positif antara jumlah uang beredar dan pertumbuhan ekonomi.

Chaitip et al. (2015) Indonesia, Singapore, Malaysia, Philippines, Vietnam, Lao PDR and Cambodia. The macro variables comprise of economic growth-wide phenomena or GDP growth rates and money growth-wide phenomena or money supply, consisting of money (M1 dalam penelitiannya pada negara AEC menunjukkan bahwa pada jangka panjang hubungan jumlah uang beredar positif dengan pertumbuhan ekonomi. Penelitian ini juga didukung oleh hasil penelitian Omodero (2019) dalam hasil penelitiannya pada negara Ghana bahwa jumlah uang beredar memiliki hubungan yang signifikan positif pada GDP perkapita pada sirkulasi uang yang menunjukkan mendukung teori moneter.

Penelitian serupa juga dilakukan oleh Hussain \& Haque (2017) bahwa jumlah uang beredar positif terhadap pertumbuhan ekonomi dengan nilai koefisien pada level $1 \%$ yang mengindikasikan memiliki hubungan yang kuat antar variabel pada jangka panjang. Hal ini sejalan dengan teori Keynes yang pada jangka panjang akan menyebabkan pertumbuhan ekonomi.

Jumlah uang beredar merupakan salah satu tools dalam kebijakan moneter, ketika ekonomi sedang lemah, daya beli masyarakat turun, hal ini akan mendorong Bank sentral untuk mengeluarkan kebijakan moneter ekspansif, dimana rasio jumlah uang beredar akan ditambahkan, bunga kredit biasanya akan diturunkan, dengan begitu para pelaku usaha akan dengan mudah untuk meminjam dana dan produktifitasnya akan bertambah, dari sektor konsumsi juga begitu, yang semula daya beli turun, akhirnya kembali membaik, sehingga perekonomian kembali stabil.

\section{Hubungan Kredit yang disalurkan oleh Sektor Keuangan terhadap Pertumbuhan Ekonomi}

Diketahui model regresi fixed effect menjelaskan bahwa variabel kredit yang disalurkan oleh sektor keuangan memiliki hubungan positif dengan pertumbuhan ekonomi di negara ASEAN-4. Nilai positif pada koefisien dcfs adalah 0.0015314 menjelaskan bahwa apabila terdapat peningkatan $1 \%$ pada kredit yang disalurkan oleh sektor keuangan maka akan meningkatkan GDP sebesar 0.0015314\% diempat negara ASEAN selama periode 1999-2018 dengan asumsi variabel lain dianggap konstan.

Sesuai dengan hasil estimasi sebelumnya yang menunjukkan hubungan positif dan pengaruh signifikan terhadap pertumbuhan ekonomi. Hubungan antara kredit yang disalurkan sektor keuangan terhadap pertumbuhan ekonomi yang ingin dicapai juga memperhatikan kondisi perekonomian, secara teori, kredit perbankan memiliki kausalitas positif dengan 
pertumbuhan ekonomi pada negara berkembang, khususnya pada negara yang di observasi yaitu negara Indonesia, Malaysia, Filiphina dan Thailand.

Kredit berpengaruh positif terhadap pertumbuhan ekonomi, juga didukung oleh penelitian yang dilakukan oleh Shahbaz et al. (2015) yang menyatakan kredit memiliki pengaruh signifikan terhadap pertumbuhan ekonomi di negara Bangladesh. Hal ini juga sejalan dengan penelitian Sipatuhar (2016) yang menyatakan bahwa meningkatnya kredit yang disalurkan oleh perbankan dapat mendorong pertumbuhan ekonomi melalui kapabilitasnya untuk menggerakkan sektor riil dengan cara menjadi akselelator skala bisnis masyarakat.

Beberapa penelitian menemukan bahwa bukan perkembangan sektor finansial yang memperkuat pertumbuhan ekonomi, tetapi pertumbuhan ekonomi yang kuat yang akan mendorong permintaan akan jasa finansial dan mendorong perkembangan sektor finansial itu sendiri (Ang \& McKibbin, 2007).

Ajogbeje (2016) dalam penelitiannya di Negeria bahwa kredit yang disalurkan positif dan signifikan terhadap pertumbuhan ekonomi, karena kredit yang disalurkan lebih banyak, akan dialokasikan pada sektor privat, sehingga kapasitas investasi pada sektor riil akan meninngkat dan mendorong pertumbuhan ekonomi. Hal sejalan dengan penelitian Olowofeso et. al (2015) di Nigeria, bahwa kredit yang disalurkan berpotensi untuk mendorong pertumbuhan ekonomi, kredit dianggap sebagai saluran terpenting dari fungsi intermediasi keuangan yang dapat memobilisasi investasi.

Prochniak \& Wasiak (2017) dalam penelitiannya juga mengemukakan bahwa kredit yang disalurkan memiliki hubungan positif dan signifikan terhadap pertumbuhan ekonomi, hal ini sesuai dengan teori model struktural yang menyatakan bahwa tingginya investasi mendorong untuk meningkatkan output pada jangka pendek yang menstimulasi permintaan pada jangka panjang atau menambah stok modal fisik.

Korelasi positif antara kredit yang disalurkan oleh sektor finansial terhadap pertumbuhan ekonomi mencerminkan bahwa ke-empat negara yang diteliti, yaitu Indonesia, Malaysia, Filiphina dan Thailand mampu mengorganisir penyaluran kredit agar tetap sesuai dengan pertumbuhan sektor riil. Kredit yang disalurkan baik untuk konsumsi, modal kerja ataupun investasi akan mendorong daya beli, gairah usaha dan tambahan investasi pada sektor riil.

Pertumbuhan ekonomi juga akan mendorong investasi baru untuk merangsang permintaan kredit baru, mendorong konsumsi dan daya beli, proses pengganda tersebut yang memberikan rembetan dan pemicu pertumbuhan ekonomi secara terus menerus.

\section{Hubungan Market Capitalization dan Pertumbuhan Ekonomi}

Diketahui model regresi fixed effect menjelaskan bahwa variabel market capitalization memiliki hubungan positif dengan pertumbuhan ekonomi di negara ASEAN-4. Nilai positif pada koefisien Inmcapt adalah 0.0420946 menjelaskan bahwa apabila terdapat peningkatan $1 \%$ pada market capitalization maka akan meningkatkan GDP sebesar $0.0420946 \%$ diempat negara ASEAN selama periode 1999-2018 dengan asumsi variabel lain dianggap konstan.

Market Capitalization menjadi tolak ukur seberapa besar kegiatan produktifitas pada sektor industri pada suatu negara. Meskipun kapitalisasi pasar memungkinkan lebih kecil dari jumlah keseluruhan aset, namun kapitalisasi pasar mampu untuk mencerminkan kontribusi sektor industri utamanya perusahaan yang ikut andil dalam pergerakan ekonomi.

Hasil penelitian ini didukung oleh penelitian Bujari et. al (2017) yang menyatakan 
bahwa meningkatnya kapitalisasi memiliki hubungan positif dengan pendapatan perkapita pada Amerika latin yang memiliki dampak yang besar untuk mengurangi tingkat bunga, dan meningkatkan pendapatan perkapita. Dokmen et. al (2015) pada penelitiannya di Nigeria menyatakan bahwa kapitalisasi memiliki efek positif pada pertumbuhan ekonomi, karena pasar saham akan memobilisasi sumberdaya dan efisiensi alokasi dana pada sektor produktif pada ekonomi dan mendorong pertumbuhan ekonomi.

Kapitalisasi pasar dapat mencerminkan keadaaan ekonomi negara, semakin besar kapitalisasi pasar mencerminkan bahwa negara tersebut memiliki menopang perekonomian yang besar pada sektor industri. Sektor industri tergolong tergolong cepa dalam perputaran uang, baik dari sektor produksinya maupun pada penjualan, hal ini membuat akses keuangan semakin cepat dan menstimulus jumlah uang beredar dan akan menghasilkan efek pengganda yang akan terus meningkatkan output.

\section{Hubungan Degree of Opennes dan Pertumbuhan Ekonomi}

Diketahui model regresi fixed effect menjelaskan bahwa variabel degree of opennes memiliki hubungan positif dengan pertumbuhan ekonomi di negara ASEAN-4. Nilai positif pada koefisien trade adalah 0.0005409 menjelaskan bahwa apabila terdapat peningkatan $1 \%$ pada market capitalization maka akan meningkatkan GDP sebesar $0.0005409 \%$ diempat negara ASEAN selama periode 1999-2018 dengan asumsi variabel lain dianggap konstan.

Berdasarkan hasil estimasi ditemukan bahwa keterbukaan perdagangan memiliki dampak positif terhadap ekonomi. Hubungan keterbukaan perdagangan merepresentasikan ukuran transaksi non domestik atau perdagangan internasional yang tediri dari ekspor dan impor. Negara yang aktif melakukan perdagangan internasional dinilai lebih efisien dalam pengalokasian sumberdaya sehingga berdampak positif terhadap pertumbuhan ekonomi (Fetahi-Vehapi et al., 2015).

Temuan Nurkse dalam Salvatore (1997) menyatakan bahwa perdagangan internasional memang mampu berfungsi sebagai suau mesin pertumbuhan (engine of growth) bagi negara-negara berkembang. Kondisi seperti ini, membuat Indonesia harus harus beradaptasi dengan tuntutan dunia yang mengalami keterbukaan ekonomi.

Hasil penelitian ini didukung oleh hasil temuan Rahman \& Mamun (2016) yang menyatakan bahwa volume perdagangan internasional akan meningkatkan pendapatan pada ekonomi domestik. Hal ini terjadi karena meningkatnya GDP perkapita, konsumsi perkapita, tabungan dan investasi akan bertumbuh dan mendorong pertumbuhan ekonomi.

Kong et al., (2021) dalam penelitiannya menghasilkan temuan bahwa keterbukaan perdagangan dapat mendorong pertumbuhan ekonomi pada jangka panjang dan pendek, efek positif dari keterbukaan perdagangan dapat efektif memperbaiki ekonomi dengan mendorong formasi modal, percepatan teknologi dan meningkatnya produktifitas. Inovasi juga menjadi dampak positif dari keterbukaan perdagangan (Scheineder,2004).

Keho (2017) dalam penelitiannya juga menjelaskan bahwa keterbukaan perdagangan memiliki hubungan yang positif dalam jangka panjang dan jangka pendek, hubungan modal dan keterbukaan perdagangan menjadi komplementer yang dapat mendorong pertumbuhan ekonomi.

Keterbukaan perdagangan dapat menjadi alternatif efisiensi dalam produksi barang, setiap negara bisa melakukan spesialisasi produk dan dapat menjadikan barang tersebut men- 
jadi komoditas ekspor unggulan, hal ini untuk memaksimalkan sumberdaya yang ada pada negara tersebut. Hal ini berdampak pada kenaikan output yang dihasilkan dan menambah kontribusi pada penambahan output yang akan mendorong pertumbuhan ekonomi. Yiheyis (2015) menyatakan bahwa kegiatan perdagangan luar negeri akan memungkinkan terjadinya transfer teknologi dari negara maju kepada negara berkembang.

\section{Kesimpulan}

Variabel indikator financial development berupa jumlah uang beredar berpengaruh positif terhadap pertumbuhan ekonomi, namun besarnya nilai jumlah uang beredar pada suatu negara tergantung sektor yang dominan pada negara tersebut. Sektor industri dan pariwisata yang dominan akan membutuhkan jumlah uang beredar yang lebih besar dibandingkan dengan negara yang agraris. Variabel indikator financial development berupa kredit yang disalurkan oleh sektor keuangan memiliki pengaruh positif terhadap pertumbuhan ekonomi. Kredit dapat meningkatkan pertumbuhan ekonomi karena kemudahan akses keuangan mampu mendorong masyarakat untuk produktif yang akan berpengaruh pada pergerakan ekonomi. Variabel indikator financial development berupa kapitalisasi pasar berpengaruh positif dalam pertumbuhan ekonomi, variabel ini memiliki dampak terbesar terhadap pertumbuhan ekonomi dibandingkan dengan jumlah uang beredar dan kredit yang disalurkan oleh sektor keuangan. Variabel ini mencerminkan besarnya perusahaan yang berkontribusi dalam sektor industri. Variabel keterbukaan perdagangan berpengaruh positif terhadap pertumbuhan ekonomi. Keterbukaan perdagangan membuat negara lebih berkembang dan dapat memenuhi kebutuhan dengan lebih efisien. Rekomendasi dari peneltian ini adalah jumlah uang beredar yang ada dimasyarakat juga harus disesuaikan dengan karakteristik pada wilayah tersebut agar tidak terjadi lonjakan inflasi karena adanya ketidakseimbangan antara supply dan demand serta indikator pengembangan sektor keuangan khususnya kredit sangat membantu untuk menstimulus pertumbuhan ekonomi. Bank Sentral harus tetap mengontrol pada batas wajar, karena apabila kredit tidak terkontrol dan hanya digunakan untuk sektor konsumtif tidak akan meningkatkan pertumbuhan ekonomi. Sebaliknya justru menjadikan ekonomi semakin lesu karena kredit macet.

\section{Daftar Pustaka}

Ajogbeje, K. (2016). Finance - Growth Nexus in Nigeria: Fragility and Development Effects. European Scientific Journal, ESJ, 12(7), 381.

Ang, J., \& McKibbin, W. (2007). Financial liberalization, financial sector development and growth: Evidence from Malaysia. Journal of Development Economics, 84(1), 215-233.

Ansong, A., \& Gyensare, M. A. (2012). Determinants of University Working-Students' Financial Literacy at the University of Cape Coast, Ghana. International Journal of Business and Management, 7(9). https://doi.org/10.5539/ijbm.v7n9p126

Asteriou, D., \& Spanos, K. (2019). The relationship between financial development and economic growth during the recent crisis: Evidence from the EU. Finance Research Letters, 28(C), 238-245.

Beck, T., \& Demirguc-Kunt, A. (2006). Small and medium-size enterprises: Access to finance as a growth constraint. Journal of Banking \&amp; Finance, 30(11), 2931-2943. 
Beck, T., Levine, R., \& Loayza, N. (2000). Finance and the sources of growth. Journal of Financial Economics, 58(1-2), 261-300.

Botev, J., Égert, B., \& Jawadi, F. (2019). The nonlinear relationship between economic growth and financial development: Evidence from developing, emerging and advanced economies. International Economics, 160(December 2017), 3-13. https://doi.org/10.1016/j. inteco.2019.06.004

Bujari, A., Calafate, C. T., Cano, J. C., Manzoni, P., Palazzi, C. E., \& Ronzani, D. (2017). Flying adhoc network application scenarios and mobility models. International Journal of Distributed Sensor Networks, 13(10), 1-17. https://doi.org/10.1177/1550147717738192

Chaitip, P., Chokethaworn, K., Chaiboonsri, C., \& Khounkhalax, M. (2015). Money Supply Influencing on Economic Growth-wide Phenomena of AEC Open Region. Procedia Economics and Finance, 24, 108-115.

Demirgüç-Kunt, A. (2006). Finance and Economic Development: Policy Choices for Developing Countries. World Bank Policy Research Working Paper, 3955(2006), 54. http://books. google.com/books?id=4o_v5jLH4KUC\&pgis=1

Demirgüç-Kunt, A., Beck, T., \& Honohan, P. (2008). Finance for all? Policies and Pitfalls in Expanding access. In World Bank Policy Research Report (Issue August).

Ductor, L., \& Grechyna, D. (2015). Financial development, real sector, and economic growth. International Review of Economics \&amp; Finance, 37(C), 393-405.

Durusu-Ciftci, D., Ispir, M. S., \& Yetkiner, H. (2017). Financial development and economic growth: Some theory and more evidence. Journal of Policy Modeling, 39(2), 290-306. https://doi.org/10.1016/j.jpolmod.2016.08.001

Fetahi-Vehapi, M., Sadiku, L., \& Petkovski, M. (2015). Empirical Analysis of the Effects of Trade Openness on Economic Growth: An Evidence for South East European Countries. Procedia Economics and Finance, 19, 17-26.

Hussain, M., \& Haque, M. (2017). Empirical Analysis of the Relationship between Money Supply and Per Capita GDP Growth Rate in Bangladesh. Journal of Advances in Economics and Finance., 2.

Ibrahim, M., \& Alagidede, P. (2018). Nonlinearities in financial development-economic growth nexus: Evidence from sub-Saharan Africa. Research in International Business and Finance, 46(C), 95-104.

Jayaratne, J., \& Strahan, P. E. (1996). The Finance-Growth Nexus: Evidence from Bank Branch Deregulation. The Quarterly Journal of Economics, 111(3), 639-670.

Keho, Y. (2017). The impact of trade openness on economic growth: The case of Cote d'Ivoire. Cogent Economics |\& Finance, 5(1), 1332820.

Kindleberger, C. P. (1963). Economic Backwardness in Historical Perspective: A Book of Essays. By Alexander Gerschenkron. Cambridge: The Belknap Press of Harvard University Press, 1962. Pp. 456. \$8.75. The Journal of Economic History, 23(3), 360-362. 
King, R. G., \& Levine, R. (1993). Finance and Growth: Schumpeter Might Be Right. The Quarterly Journal of Economics, 108(3), 717-737.

Kong, Q., Peng, D., Ni, Y., Jiang, X., \& Wang, Z. (2021). Trade openness and economic growth quality of China: Empirical analysis using ARDL model. Finance Research Letters, 38, 101488.

Lee, J. (2005). Financial Intermediation and Economic Growth Evidence from Canada. Eastern Economics Association, New York.

Levine, R. (1997). Financial Development and Economic Growth: Views and Agenda. Journal of Economic Literature, 35(2), 688-726.

Levine, R., \& Zervos, S. (1998). Stock Markets, Banks, and Economic Growth. American Economic Review, 88(3), 537-558.

Lucas, R. E. (1988). On the mechanics of economic development. Journal of Monetary Economics, 22(1), 3-42.

Mankiw, N. G. (2006). Macroeconomics (6th edition). New York: Worth Publishers.

Musila, J., \& Yiheyis, Z. (2015). The Impact of Trade Openness on Growth: the Case of Kenya. Journal of Policy Modeling, 37(2).

Odhiambo, N. M. (2008). Financial depth, savings and economic growth in Kenya: A dynamic causal linkage. Economic Modelling, 25(4), 704-713.

Omodero, C. O. (2019). Effect of Money Supply on Economic Growth: A Comparative Study of Nigeria and Ghana. International Journal of Social Science Studies, 7(3), 16.

Ono, S. (2017). Financial development and economic growth nexus in Russia. Russian Journal of Economics, 3(3), 321-332.

Pradhan, R. P., Arvin, M. B., Hall, J. H., \& Nair, M. (2016). Innovation, financial development and economic growth in Eurozone countries. Applied Economics Letters, 23(16), 1141-1144.

Prochniak, M., \& Wasiak, K. (2017). The impact of the financial system on economic growth in the context of the global crisis: empirical evidence for the EU and OECD countries. Empirica, 44(2), 295-337.

Purwono, R., Yasin, M. Z., \& Khoerul Mubin, M. (2021). Correction to: Explaining regional inflation programmes in Indonesia: Does inflation rate converge? (Economic Change and Restructuring, (2020), 53, 4, (571-590), 10.1007/s10644-020-09264-x). Economic Change and Restructuring, 4. https://doi.org/10.1007/s10644-021-09343-7

Rahman, M. M., \& Mamun, S. A. K. (2016). Energy use, international trade and economic growth nexus in Australia: New evidence from an extended growth model. Renewable and Sustainable Energy Reviews, 64, 806-816.

Salvatore. (1997). Ekonomi Internasional, Edisi Kelima (diterjemahkan oleh Haris Munandar). Jakarta: Erlangga 
Scheineder, Patricia Higino. (2005). International Trade, Economic Growth and Intellectual Property Rights: A Panel Data Study of Developed and Developing Countries. Journal of Development Economics, 78, 529-547.

Seven, Ü., \& Yetkiner, H. (2016). Fin-ancial intermediation and economic growth: Does income matter? Economic Systems, 40(1).

Shahbaz, M., Rehman, I. U., \& Muzaffar, A. T. (2015). Re-Visiting Financial Development and Economic Growth Nexus: The Role of Capitalization in Bangladesh. South African Journal of Economics, 83(3), 452-471.

Sipatuhar, M. A. (2016). Keterkaitan Kredit dan Kelembagaan Perbankan Indonesia pada Perekonomian Nasional dan Regional (Linkage of Indonesian bankCredit and Institutional on National and Regional Economy) Sekolah Pascasarjana Institut Pertanian Bogor, Indonesia

Vergara, R. J. (2018). Financial development, institutional investors, and economic growth. International Review of Economics and Finance, 54(August 2017), 218-224. https://doi. org/10.1016/j.iref.2017.08.009 